\title{
THE ICONOGRAPHY OF DIVINITY: KALI AS A POWER-CLUSTER OF TEN DIFFERENT GODDESSES
}

\author{
Jiblal Sapkota, Associate Professor of English \\ Tribhuvan University, University Campus, Kirtipur \\ jblsapkota@gmail.com
}

\begin{abstract}
This article is an exploration of Kali, a Hindu deity, through Panofskian three-tiered meanings of a visual art: pre-iconographical description, iconographical analysis and iconological interpretation. It presents neither a dogmatic nor an erotic interpretation of Kali but a purely objective analysis of the Hindu deity. It is argued that Kali has layers of implications, associations and meanings as well as multiple forms, namely Kali, Chinnamasta Kali, Tara, Bhuvaneshwori, Bagalamukhi, Dhumbavati, Kamala, Bhairavi, Sodasi, and Matangi. Each form is also associated with different mythologies, allegories and allusions of their origin. It is assumed that this article has had great significance in the academia as well as for the academicians and academics who are interested in carrying out research works, with an objective description, analysis and interpretation of any visual art.
\end{abstract}

KEYWORDS: Pre-iconographical description, iconographical analysis, iconological interpretation, Mahavidyas, visual culture

\section{THE CONTEXT}

On the sunny fascinating Saturday morning of Mahaashtamee, on 26th Ashwin 2070 that it happened, I was sipping my morning tea sitting on the verandah of my house in Butwal. It was truly a blessing in disguise. I was not yet fully ready to attend the Durga Pooja, flipping through Dainik Patra, a Nepali National Daily Newspaper of which I worked as Founder Editor-in-Chief for nine years. Suddenly, my cell phone started ringing. It was a phone call from Dr. Min Pun, Lecturer of English, working at P.N. Campus, Pokhara, as well as Chief Editor of Crossing the Border: Journal of Interdisciplinary Studies who reminded me of my promise of writing an article for his journal. Although I had forgotten the promise during my last visit to Pokhara on 6th Ashwin 2070, I reiterated my promise. Dr. Pun's phone and my reiteration made me serious about the matter and hence I started thinking of different issues for the article. I felt a kind of gestation in my mind. There was a splendid Nawa Durga Pooja near my house. I was invited to attend the Pooja since my arrival in Butwal from Kathmandu. Keeping the promise alive in my mind, I attended the Pooja with inquisitive concentration and thought. I listened to the sermon of the pundits about the immanence, valor, ferociousness of the Goddess Kali and her different forms. I observed different idols of Kali that were kept on the platform for worshipping. As a social custom, I was attending the Nawa Durga Pooja, but my mind was boiling over searching innovative issue and interesting topic for the article. When I observed the Kalratri Pooja, I felt a kind of electric current got flickered into my mind, with a firm determination to work on Kali, especially dealing with her multiple forms and 


\section{Crossing the Border: International Journal of Interdisciplinary Studies}

associations. As a result, I have made up my mind to deal with the present paper is the outcome of this recent past visit to my hometown Butwal as well as my own humble dedication to Dashain, the great festival of all Hindus.

\section{INTRODUCTION}

This paper critically analyzes the three-tiered meanings of Goddess Kali, one of the most popular deities in Hindu pantheon who usually represents the dark side and contrary aspects of the cosmos. She challenges the very concept of divinity by her naked form and her association with violence. Hence, over the centuries, she has been representing as a whole gamut of conflicting images from a dangerous bloody goddess to a benign goddess. In order to understand Kali, it is important to go through her visual forms such as shape, size, colour, posture, surrounding, etc. It is also necessary to understand her origin, mythologies, metamorphosis, allegorical associations and ideological interpretations. In this paper, I have attempted to present her pre-iconographical description, iconographical analysis and iconological interpretation as expressed by Erwin Panofsky, the Saussure of Visual Culture, in his epoch-making essay "Iconography and Iconology: An Introduction to the Study of Renaissance Art."

The outstretched tongue of Kali distinguishes her from all other Hindu goddesses. Her outlook, as her unbounded hair, nakedness, association with blood and unbridled sexuality shows, has challenged the conventional image of divinity. So, for a uniformed eye, she appears to be more as blood thirsty rather than a manifestation of the divine.

In this regard, to understand Kali's pre-iconographical description, it is neces-

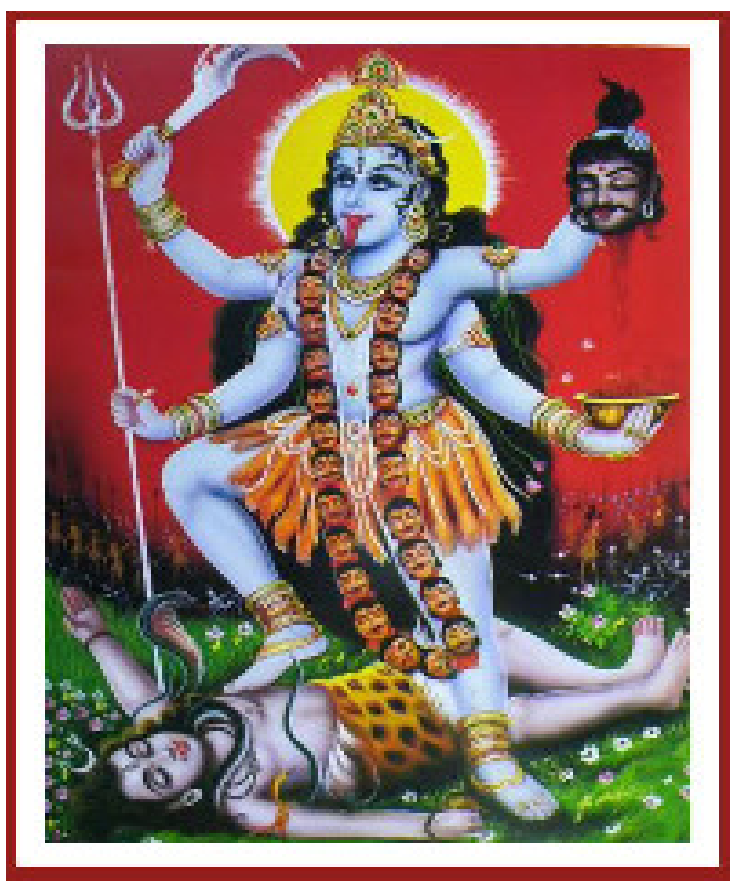

Fig. 1. Kali, Spirituality. Retrieved 22 Oct. 2013 from http://www.iloveindia.com/spirituality/goddesses/kali/. sary to appreciate the Hindu concept of divine. Similarly, Hindus have taken divine in various forms such as humans, animals, plants and minerals where each form has its own ritual and its respective narrative serves as a gateway to realize the ultimate unmanifest godhood. According to David Kinsley, "male form of divine represents spirituality and the female form symbolizes the reality" (22). But as a "goddess," Kali embodies material realities and spirituality, a totality of nature, as she is herself a creator as well as a destroyer. The picture below is the Hindu goddess Kali upon which, now onwards, I look spiritually as a follower of Hindu religion and aesthetically as a critic of visual art. 


\section{THE ICONOGRAPHY OF DIVINITY}

\section{PRE-ICONOGRAPHICAL DESCRIPTION OF KALI}

Pre-iconographical description deals with factual and expressional representation of visual art. Panofsky speaks of it as the primary or natural subject matter. At this level, the onlooker, according to Panofsky, has to identify with "[p]ure forms that is: certain configurations of line and color representation of natural objects such as human beings, animals, plants, houses, tools and so forth - artistic motifs. An enumeration of these motifs would be pre-iconographical descriptions of the work of art" (221). The visual forms of the work of art are considered to analyze a visual text like this. The following paragraphs show the pre-iconographical descriptions of Kali from different angles.

\section{A Goddess in Different Forms}

Hindus have shown the idea of God in different forms where each form brings different sets of symbols which communicate the Hindu understanding of their life and divinity. In this context, Elizabeth Harding in her book Kali: The Black Goddesses of Dakshineswar states that "Hindus have many Gods and Goddesses each evoking one aspect of divinity so, it is impossible to believe in an absolute entity or to believe in one form of God" (2). Different gods and goddesses show different aspects. For example, Shiva evokes world-renouncing idea whereas Vishnu evokes world- affirming ideas. The goddess Kali can be described as having a frightening appearance. She can usually be seen in her black or dark texture along with a long, disheveled hair. Her iconography is intentionally too difficult to look upon; this requires attention and even 'fearlessness'.

Kali can be represented in many forms as a playful child, a voluptuous woman, a warrior, or a decrepit old hag. As a young woman, she is in a form of mother goddess. As a warrior, she is a defender, a preserver, or a destroyer. As a hag, she represents the impermanence of all things that physical manifestations of beauty are passing through, which is the inner beauty of divine. As shown in the picture, we can see her outstretched tongue, her dark complexion, her unbound hair, a garland of cut human heads and her girdle of arms around her waist. We can also see her nakedness of the body with her four hands, and her standing on the chest of Shiva. In this way, these visual images, her postures and surroundings leave a different impact on the onlookers.

\section{Outstretched Tongue}

In Hindu culture, there are many Goddesses who are naked in form and are associated with death and blood. As such is Kali, who can be seen as in Chandi, Chamunda, Bhairavi and Bhagwati. But the only thing that distinguished Kali from other goddesses is being with her outstretched tongue. There are different reasons behind having such a tongue in Hindu mythology. One of them is that, as Seema Mohanty describes, because "Kali spreads her tongue to drink the blood of the demon Raktabija before it touches the ground and spouts Rakta-bija before closes" (Mohanty 10). Another narrative is that "Kali sticks out her tongue in embarrassment on realizing that she has stepped on her own husband in her bloodlust" (10). Usually, we can see that in Kali's temple, her tongue is smeared with blood of sacrificed animals by her own tongue. According to Mohanty, "she teaches her devotees-she sees through their social façade and she knows the dark desire which they are trying to deny or trying 


\section{Crossing the Border: International Journal of Interdisciplinary Studies}

to suppress" (11). Beside all these, she resides in the household of Hindu people and serves as a guardian of a family.

\section{Dark Complexion}

In Tantric Vision of the Divine Feminine, David Kinsley states that her name "Kali" means "black" (24). Usually, she is associated with all things black: her skin is dark; her hair is black; and her priests wear black dress, worshipped on the new moon "black nights. Furthermore, Kinsley mentions, "The black Kali is known as Smashana Kali and the purple or blue Kali is known as Bhadra Kali" (24). Artists often paint Kali not black but purple or blue. Similarly, according to Mohanty, "The black Kali is called Smashana Kali and enshrined in crematoria, while the blue or purple Kali is called Bhadra Kali or Dakshina Kali .... Kali refuses to endorse traditional concepts of beauty and auspiciousness" (11). By this, we also know that Kali, in Hindu mythology, represents the Goddess of dark and black aspects.

\section{Unbound Hair}

Clio Whittaker, in his book Oriental Mythology, presents that "in Hindu tradition hair can be taken as a metaphor of sexuality-poised for fulfillment in the virgin, controlled in married women whereas stripped away in widow women, an unmarried virgin plaits her hair, the married women oil and comb their hair and widow shave their hair" (52). Kali's hair is unbound, which indicates her sexuality as unfettered by any social norms. As it indicates the wild, untamed site of forest in which sex and violence are unbridled. Similarly, in the same book, Whittaker further states that "Devi always unbinds her hair when angry or upset, or when she is called to battle" (52). It is believed that Kali is said to be originated in order to destroy the evil beings; so she is usually seen in the battle field with her unbound hair.

\section{A Garland of Cut Heads and Girdle of Arms}

As can be seen in the picture, Kali wears a garland of cut human heads around her head. Many believe that they are the heads of demons. As Kali by doing this protects the world from destruction. Those heads are also supposed to be of human beings who have been sacrificed or who have sacrificed themselves to her. According to metaphysicians, as Mohanty argues, the heads are symbols of the ego that must be offered to Kali by those seeking liberation from worldly ties" (12-13). This not only shows that Kali throws out the ego of human beings but she also gives liberation to humans from worldly ties. The garland of cut human heads also denotes that she has controlled over human beings. She is also the recipient of ardent devotion from her countless devotees, who approach her as a mother. Kali has also put on girdle of arms around her waist, which according to Mohanty, is the process to free her devotees from the "cycle of death and rebirth" (3). Her standing upon the chest of Shiva indicates the ultimate bliss of ego being gone, a transformation, or a reunion of divine spark within human beings. Kali thus has become the explanation for the inexplicable deaths of newborns.

\section{Nakedness of Her the Body}

Ajit Mookerjee, in her book Kali: The Feminine Force, states that "Kali is usually seen naked, her nakedness represents nature" (4). This means that Kali represents 


\section{THE ICONOGRAPHY OF DIVINITY}

the nature. As Kali is considered the half of Shiva, she is also like other goddesses a virgin, where this term virgin as argued by Kinsley "indicates the Devi who belongs to no man" (4). Nature is supreme, shedding and reclaiming its fertility as its own volition. So, the nakedness of her body denotes motherly love, care and affection to all the creatures of the world.

\section{Four Hands}

As usually in Hindu tradition, gods and goddesses are depicted with having more heads and hands than ordinary human beings. Kali, in most of the creation, can be seen having four hands. According to the forms and scriptures being worshipped, those hands bear different weapons: sickles, sword, axe and whip. Often, Kali is shown holding a cut male head in the one hand and the blood dropping collected in a cup. Different postures can be seen in Bhadra Kali and Dakshina Kali, which are associated with protection and blessing.

\section{Postures and Surroundings}

In most of the images of Kali, she appears to be walking from the south towards the direction of devotees where she accidentally steps on Shiva, with her left foot on his chest. For support In order to support this argument, Mohanty in her book The Book of Kali writes that "Left is said to be associated with the feminine instinct, whereas right is associated with masculine" (18). Kali always amidst death and decay, in different pictures of her found in battle field and cremation ground. She is often surrounded with gloomy and gray color. The battle ground witnesses the collapse of culture and orderly conduct, giving way to unbridled violence as humans lose their range. The cremation ground witness the triumph of nature as death claims one and all, which shows that she was created in order to control the violence that humans cannot control.

\section{The Origin, the Myth}

To understand the origin of Kali as an important part of Hindu pantheon, we have to go through how Hinduism evolved and transformed over centuries, as she is located in the battle-field or in the periphery of Hindu society. Describing the origin of Kali, Mohanty argues:

The early phase, which is also known as 'Vedic' period, focuses on the sacrificial ceremony which is also known as 'yagna', through which these priests tried to invoke celestial beings and control the working of the world. But after the rise of heterodox belief system as Buddhism in fifth century to fifteenth century AD, Hinduism becomes more theistic: a personal God, shaped in the form of songs, stories, enshrined in temples, evoked through the rituals or puja. This process was extended by brahminical appropriation, accommodation of non Vedic, different tantric, deities, beliefs so it is by this non Vedic space by which Kali in all probability entered into the Hindu pantheon. (89)

This shows the origin of Kali. As in Vedic period there were rituals of sacrifice known as yagna and this process used to control the working of the world. But after the rise of Buddhism, Islam, and Christianity, Hinduism becomes more theistic and during that period the Goddess Kali entered into the Hindu pantheon.

In this way, we get different layers of importance in her pre- iconographical description. By looking into her physical structure, she was developed as a symbol 


\section{Crossing the Border: International Journal of Interdisciplinary Studies}

of Shakti or power to destroy the evil. Although today Kali is worshipped as an autonomous goddess, manifesting in a variety of forms looking through the history of celebration of the Hindu deity, we notice that she has been visualized as part of a divine female collective, as the embodiment of one of the three Devi powers, and the other face of the two faced village goddesses. Furthermore, it is said that the name of Kali first appeared in the Upanishad Mundaka, which was written around in the fifth century BC. Kinsley in his book Hindu Goddesses states, "In Upanishad Kali is one of the seven tongues of Agni, a god of fire" (28). But after the brief mention of Kali in the Mahabharata, she was raised to prominence in the Devi Mahatmya, which is also known as Chandi Patha around the Sixth Century AD. With compilation of chronicles also known as Puranas and Tantras from fifth to fifteenth century, Kali's tales were told and her invocations were recorded with increasing frequencies. The standard pre-iconographic representation in which Kali is known nowadays in most of the households came into existence only in the seventeenth century. Similarly, Kinsley in his book remarks:

Kali worship in mainstream religion had less to do with her mention in Puranic scriptures, and more to do with her identification with village- goddess cults such as Bhagavati of Karala, Yellamma of Karnataka, Kali Bai of Maharashtra, Tara of Bengal, Bhadra Kali of Andra, Kalika Mata of Nepal, Rajasthan, Gujarat and Mari Amman of Tamil Nadu. (102)

She is one Goddess but has multiple forms and meanings as she has been given different names since the beginning of its existence, such as Bhagwati, Yellamma, Kali Bai, Tara, Kalika and so on. She is the fierce guardian of the frontiers who are threatened by diseases and disaster unless appeased her with blood- scarifices, self- mutilation, hookswinging, fire walking and offerings of bridal finery. Only different names are given in different places but she has been worshiped with the same belief everywhere as a creator and destroyer of evil forces which humans cannot avoid.

In general, then, even though she would never occupy the central position on Hindu deity, she is in the central position in 'tantrism'. To this reference, Kinsley in his book Tantric Vision of Divine Feminine writes, "An underlying assumption in tantric ideology is that reality is the result and expression of the symbolic interaction of male and female, Shiva and Sakti, the quiescent and the dynamic, and other polar opposites that is interaction produce a creative tension" (122). Shiva is taken as a source of the Tantras or the source of truth and Kali is the source to gain 'moksha' or salvation.

The above mentioned pre-iconographical descriptions of Kali show the factual and expressional representation of Kali. This also shows some of the description of her forms, meaning of her outstretched tongue, her dark complexion, reasons behind her unbound hair, four hands, her origin and so on. This not only gives a general meaning, but also tries to show the Hindus concept of Divine.

\section{ICONOGRAPHICAL ANALYSIS OF KALI}

The second tiered meaning of visual images as suggested by Panofsky is iconographical analysis. This not only denotes a particular person, place or thing but also ideas and concept to it. He glosses it as "Secondary or conventional subject matter" (221). Similarly, Jiblal Sapkota in his article "Panofskian Three Tiered Meaning of Three Cartoons" writes, "in the iconographical analysis the analyst has to connect artistic motifs 


\section{THE ICONOGRAPHY OF DIVINITY}

and their combination with themes or concepts" (127). Correct iconographical analysis presupposes a correct identification of the artistic motifs. In this context, iconographi$\mathrm{cal}$ analysis deals with the images, stories and allegories related to the subject, much more than the practical experience.

\section{Tales Told}

In order to get the iconographical significance of Kali, we have to go through the stories or tales related to her as these stories help establish the characteristics of Hindu deities. These stories can be found in epics such as Ramayana, Mahabharata and also in chronicles such as the Puranas. These stories reach to the common people by vernacular retellings where each retelling has a character of its own. Over the centuries, we find many retellings of Kali's tales, which have portrayed her in different forms. In some, she has been manifested as a divine range whereas in some, she appears to be the final defender of the world to whom the gods turn when all the measures got failed.

Kali has also been shown as the goddess who demands human sacrifices. But it is clear that in some stories we can see a clear relationship between the narrative and her characteristic form and in others, the narrative form is totally indifferent to the form.

\section{Manifestation of Divine Range}

One of the earliest stories of Kali can be found in the Devi Mahatmya, where Kali plays central role and is shown as the embodiment of Durga's range when she loses composure. It is said that once the gods gathered on the bank of the river Ganga in order to evoke Devi and get her help to overpower two demons known as Shumbha and Nishumbha. Parvati, the consort of Lord Shiva, who happened to be passing through, heard their prayer. Instantly goddesses emerged through her body. Since she emerged by the cell of Parvati, she was named as Kaushiki. As she looked like a warrior, quite unlike the domestic Parvati, she was also known as Chandika. Chandika was very beautiful as she was also called Lalita and Vimala. News of her beauty soon reached to Shumbha and Nishumbha, they wanted to make her their queen and sent her a marriage proposal. To their surprise, she sent the following reply, "I shall accept as husband only to the man who can defeat me in battle" (Mohanty 87). By this reply, Shumbha and Nishumbha ordered their minions to bring Chandika in front of them by force. They found Chandika in a top mount Meru. She sat on a lion with a smile in her face. At the sight of demons, Chandika's face blackened with anger and from her dark frowning brow Kali emerged-a dark, gaunt, with a bloodshed eyes, a sharp fang and lolling tongue. She let out a shrill war cry and rushed towards them. The demon army raised their bows but before they could shoot a single arrow, Kali was upon them. She broke their bows and devoured their elephants. She chewed them alive with her fangs; she disemboweled a few demons with her bare hand, earning the title of Raktadantika, the red teeth. Finally, Kali came to face Shumbha and Nishumbha with a single swipe of her sword. She defeated both of them and gifted their heads to Chandika who declared that by defeating them she will be also known as Chamunda and she successfully restored order in the world. To celebrate this victory, the gods composed a hymn, which is now known as Chandi-Patha

In Shiva Purana, composed before six centuries BC, Kali, has been presented as a manifestation of Shiva: 


\section{Crossing the Border: International Journal of Interdisciplinary Studies}

Sati strode into her father's house and immolated herself in sacred pavilion to protest against Shiva's exclusion from the yagna. Daksha, however, continued with the ceremony. When news of Sati's death and Daksha's indifference reached Shiva, he was furious that he plucked a lock of his hair and lashed it against the ground to create an army of demonic beings led by the fierce looking warrior Virabhadra and his equally ferocious companion, the goddesses Bhadra Kali. Virabhadra and Bhadra Kali rushed into Daksha's house and set about disrupting the ritual. They kicked the sacred vessels, spat on the offerings, attacked the assembled guests, scared away the gods, and finally beheaded Daksha. (Mohanty102)

It shows that Sati sacrifices herself for the exclusion of Shiva and in that situation Shiva plucked his lock of hair and lashed it in the ground from that Bhadra Kali and Virabhadra were formed.

In Devi Mahatmya, Kali is presented as the ultimate deliverer called to salvage a situation which seems to be uncontrolled. In this context, Mohanty in The Book of Kali states:

Having wounded Rakta-bija with a variety of weapons, Durga and her assistants- a fierce band of warriors known as the Matrikas-find they have only aggravated the situation: as Rakta-bija bleeds more and more profusely from his wounds, the battlefield increasingly become filled with replicas of Rakta-bija. Desperate, Durga summons Kali. Kali spreads her tongue across the battlefield, swallows in one gulp the swarm of blood-born demons and sucks the blood from the original Rakta-bija until he falls down. (48-49)

Mohanty's remarks support the proposition that Kali as the ultimate deliverer called upon to salvage a situation which seems to have been uncontrollable. This iconographical analysis of Kali gives different myths and stories related to her origin. This analysis shows that God is the spiritual principle and Devi is the material principle.

\section{ICONOLOGICAL INTERPRETATION OF KALI}

The third tiered meaning of visual image, according to Panofsky, is iconological interpretation. He writes it as "intrinsic meaning or content" (222). Supporting this argument Sapkota in his article writes, "iconological interpretation arises from synthesis rather than analysis" (128). A correct analysis of images, stories and allegories is the pre-requisite for the correct iconological interpretation.

Talking about the iconological interpretation, it is said that Kali allows one to get better perception by enabling the complete picture. She helps one to see behind the bounteousness of the other goddesses who have appeared in the benign forms. She has revealed the insatiable hunger, which logically must lie behind their amazing fecundity and liberality. Furthermore, Kali helps an individual to see their overall roles in the cosmic drama. She gives a real reflection where one has come from and where one is going. She allows one to see himself or herself as merely one being in an endless series from the ever recurring cycles of life and death, which constitute the inner rhythm of the divine mother. Similarly, Kinsley in his book Tantric Vision of Divine Feminine states that "Kali's shocking appearance and unconventional behavior confront one with an alternative to normal society. To meditate on the dark goddess, or to devote oneself to her, is to step out of the everyday world of predictable dharmic order and enter a world of reversals, opposites, contrasts and in doing so to wake 


\section{THE ICONOGRAPHY OF DIVINITY}

up to new possibilities and new frames of references" (130). Her appearance makes one feel comfortable for ones existence; it helps to step out of the predictable order and helps to move to the new frames of reference. In her uniqueness, strangeness, indeed, in her perverseness, Kali is the kind of figure who is capable of shaking one's comforting and native assumptions about the world and come up with new insight.

There are different stories or tales about the different forms of Kali. The Goddess Kali is believed to be the Shakti cluster of ten different goddesses. The ten different forms of Kali in Hindu mythology are also known as Mahavidyas. The origin of these ten Mahavidyas takes place in the context of the story of Sati and Shiva. According to Kinsley:

Sati's father Dakshya decided to form a great sacrifice and he invited all the gods and goddesses but the one couple who was not invited was Sati and Shiva. ... Sati announces to Shiva that she will go to sacrifices in order to disrupt it but Shiva forbids her by which she loses her temper. At that situation she assumes a dreadful appearance (Kali) and then by that form she multiples herself into nine different forms: Tara, Chinnamasta, Bhuvanesvari, Bagala, Dhumavati, Kamala, Matangi, Sodasi and Bhairavi. (26)

This mythological context for the appearance of these ten forms known as Mahavidyas makes it clear that they are meant to be fearsome deities. Even though some of the deities in this group are also taken as beautiful and unthreatening, for the most part they are fearsome but they are not described as warriors, and the goddesses are only mentioned for playing the roles of warriors. Likewise, Mookerjee in her book Kali: The Feminine Force mentions that "the Mahavidyas are not mere feminine versions of Vaisnava Avataras which was appeared to defeat demons who threaten the world" (62). The fearsomeness of these goddesses is also seen to be related with the context in which they are propitiated. These deities are mostly known primarily in Tantric literature as they play an important role in Tantric texts and practices.

\section{CONCLUSION}

The descriptive, analytical and interpretative meanings of Kali help derive the conclusion that Kali is one goddess but has multiple forms and meanings within her. The pre-iconographical description of Kali is the description of external visual features, which can be identified by the sensory and practical experience of the onlooker. The iconographical analysis deals with the mythologies, stories, or allegories related to the Hindu deity Kali. The iconological interpretation includes synthetic intuition, cultural symptoms, tendencies of human mind and ideological values of Kali. The ten different forms of goddess Kali namely Kali, Chinnamasta Kali, Tara, Bhuvaneshwori, Bagalamukhi, Dhumbavati, Kamala, Bhairavi, Sodasi and Matangi represent Kali as Shakti Cluster of ten goddesses, which are also known as ten $M a$ havidyas, the ten great transcendental wisdoms.

Kali has made to re-examine the notion of divine as she was associated with beauty and love, but she is neither beautiful nor loving. She is dark, gaunt and bloodthirsty. She is life who feeds on life. She is unbridled and impersonal sex and violence that makes the cycle of existence possible. She stands beyond the worldly prejudices and values. She encompasses the totality of life and nature.

In the contemporary human society, as Kali has different forms and meanings within her, human beings also have multiple identities, roles and meanings within 


\section{Crossing the Border: International Journal of Interdisciplinary Studies}

them. Even the secular beings have multiple values. Life and death constitute a process of giving and receiving, a process through which the energy of the Mahvidyas is continuously recycled among the creatures of the world.

\section{WORKS CITED}

Harding, Elizabeth. Kali: The Black Goddess of Dakshineswar. Chigago: York Beach, 1933. Print.

Kinsley, David. Hindu Goddesses. Delhi: Jainendra Press, 2005. Print.

---. Tantric Visions of the Divine Feminine. Delhi: Motilal Banarsidass Publishers, 2008. Print.

Mohanty, Seema. The Book of Kali. Delhi: Penguin Books India, 2004. Print.

Mookerjee, Ajit. Kali: The Feminine Force. London: Thames and Hudson Ltd., 1998. Print.

Panofsky, Erwin. "Iconography and Iconology: An Introduction to the Study of Renaissance Art." The Art and Art of History. Ed. Preziosi Donald. New York: Oxford University Press, 2009: 220-35. Print.

Rinehart, Robin, ed. Contemporary Hinduism: Ritual, Culture and Practice. California: ABC-CLIO, Inc., 2004. Print.

Sapkota, Jiblal. "Panofskian Three-Tiered Meanings of Three Cartoons." The Outlook: Journal of English Studies 6.1 (Aug. 2012): 126-32. Print.

Whittaker, Clio. An Introduction to Oriental Mythology. Bludell Street: The Apple Press, 1989. Print. 